\title{
Study on the Effectiveness of the Equity Incentive Plan of Private Enterprises in Zhuhai City: Taking TongWang Technology as an Example
}

\author{
Junda Yang ${ }^{1}$, Yun Xia ${ }^{1}$, Liu Yang ${ }^{1} \&$ Zhongtao Zhang ${ }^{1}$ \\ Finance Department of International Business School, Jinan University, Zhuhai, China \\ Correspondence: Yun Xia, Finance Department of International usiness SchoolB, Jinan University, Qianshan Road \\ 206\#, Zhuhai City, Guangdong Province, Post No.519070, China. Email: 13676097885@163.com
}

Received: September 30, 2018

Accepted: October 18, $2018 \quad$ Available online: October 24, 2018

doi:10.11114/aef.v5i6.3714

URL: https://doi.org/10.11114/aef.v5i6.3714

\begin{abstract}
The study of the effectiveness of equity incentive has always been the focus of the academic circle. Whether it is foreign or domestic, there is no conclusive evidence at present. This paper is divided into three parts: Firstly, it summarized the literature research conclusion of equity incentive at home and abroad. Secondly, the author analyzes the incentive scheme and the implementation effect of the equity incentive scheme of the same-looking science and technology as an example. Finally, the author puts forward the feasibility of improving equity incentive measures for private enterprises in China.
\end{abstract}

Keywords: equity incentives, stock option, TongWang technology

\section{Introducation}

In the 1950s, the US began equity incentives to executives.By the end of the 19th century, $90 \%$ of the top 1000 firms granted stock options to their executives.Compared with USA enterprises, the administrative intervention of China is serious, the management system is not perfect, and the management method of equity incentive is very late.On Dec. 31 , 2005, China's securities regulator issued a "Management Measures of Equity Incentive in Listed Companies (Trial)".Since then, the business community has followed the USA enterprises and launched the equity incentive scheme, so that the managers and the shareholders' interests tend to be consistent, so as to improve the management enthusiasm of the managers, hoping to improve the performance of the enterprises, so that the shareholders can gain greater benefits. However, the academic circle's discussion about whether the equity incentive can improve the performance of the enterprise is in full swing. Some scholars believe that the executive shares have a linear positive relation with the performance of the enterprise. There is also a scholar's opinion that the stock ownership incentive makes the executive stock ownership and the enterprise performance nonlinear function relationship because of the different holding proportion. Even some scholars believe that executive ownership does not correlate with corporate performance.It can be seen that there is still debate about the validity of equity incentive China.Taking stock ownership incentive measures of the private listed companies in Zhuhai city as the case study object, the paper investigates the specific measures and results of equity incentive of TongWang science and technology, and puts forward the feasibility proposal from the angle of the enterprise equity incentive specific plan, therefore providing a useful reference for the improvement of equity incentives in private enterprises in China.

\section{Theoretical Foundation and Literature Review}

\subsection{Literature Review Abroad}

The effectiveness of equity incentive has always been the focus of the academic debate. The researches by foreign scholars on equity incentive started early.Jensen and Mecling (1976) stated to investigate the relationship between executive ownership and corporate performance, and they think the greater the proportion of executive ownership, the better the company's performance.Mehran (1995), by taking the sample of 153 manufacturing enterprises sampled randomly from 1979 to 1980 , made an empirical study on the relationship between reward structure and corporate performance of managers. The results show that corporate performance is positively related to the proportion of managers holding stock option. Bickley et al. (1985) studied the incentive scheme from the angle of stock price. The results show that the long-term equity incentive scheme of listed companies is positively correlated with its share price. Meanwhile, three domestic scholars, such as Morck (1988), by taking 371 families as samples, and studied the 
relationship between owner's shares and corporate performance. The results showed that when shares are in the range of $0-5 \%$, they are positively correlated. Between $5 \%$ and $25 \%$, they are negatively correlated. When the shareholding proportion exceeds $25 \%$, these two are positively related.At the same time, some scholars have put forward the opposite conclusion.Demsetz and Lehn (1985) took 511 companies in 1980 as samples, and returned to the company's internal shares by using the rate of return as corporate performance index, and found that there was no significant correlation between them. The empirical results made by Himmelberg et al. (2000) also showed that management shares have not improved their share of ownership.It can be seen that the evidence from the study of the effectiveness of foreign ownership incentive has not been convergent, and there is no conclusive evidence at present.

\subsection{Overview of Domestic Related Literatures}

The corporate governance structure of listed companies in China is relatively weak. The incentive system of stock right is not perfect. Therefore, the domestic scholars' study on equity incentive started very late, but the research angle is very diverse, the research conclusion has obvious difference, mainly include the following three research results:

The equity incentive is positively related to the company's performance. Liu Guoliang and Wang Jiasheng (2000) studied the relationship between the company's operating performance and the dispersion of the shareholder structure and the stock-equity of the company owned by the manager in 1999. The results showed that they are positively correlated. Zhou Jianbo and Sun Jusheng (2003) put forward that the company with equity incentive, before the equity incentive, the performance is generally higher, the previous scholar's related research may have selective bias. They believed that companies with higher growth rates are significantly positively correlated with the increase in stock ownership by managers. Huang Guitian and Zhang Yue (2008) made further tests on the effectiveness of the equity incentive scheme by using the non-parameter Matching method for the listed companies which proposed the equity incentive scheme in 2007. The study showed that the equity incentive has a significant positive influence on Tobin's Q value.

The equity incentive and company's performance are negatively correlated and not related. Yu Honglin (2006) selected 933 listed companies from 2001 to 2003, and found that there was a significant negative correlation between the managers holding level of state-owned listed companies and the Tobin's Q value, while all listed companies and non-state-owned listed companies had no significant correlation. Wang Qiuxia and Chen Xiaoyi (2009) adopted the factor analysis method to evaluate the economic performance of 19 listed companies that have already implemented or have announced the implementation of equity incentive in 2006-2007, and the relevant analysis method is used to draw the conclusion that: There is no significant correlation between the proportion of operator's share and the performance of business operation.

In recent years, scholars have more extensive research on equity incentive, which is not limited within the company's performance. In 2002-2009, Xia Yun (2014) analyzed the effect of executive power on R \& D investment by using power to influence the equity incentive. The results showed that the larger the executive power, the smaller the incentive effect of equity incentive to R \& D investment. While Tian Xuan and Meng Qingyang (2018) take the data of listed enterprise data of 2001-2016 as sample and the results indicate that both stock option and restrictive stock have significant incentive effect on corporate innovation. However, when stock price is closer to power price, the punitive damages of restricted stocks to executives can affect the power of innovation, while stock options protect executives and motivate them to innovate. Xiao Shuguang and Yang Jie (2018) used the PVAR method to study all the listed companies listed in the equity incentive implementation record in 2011-2016, and the results show that the executive equity incentive has a promotion effect on the advanced technology structure and the high-level employee structure for a long time.

Is the equity incentive beneficial to the development of shareholders or enterprises? Taking stock ownership incentive measures as the case study object in Zhuhai city's private enterprises, this paper analyzes the specific scheme of equity incentive and the enterprise performance and manager behavior after equity incentive from the TongWang technology. The three aspects of market reaction are to investigate the concrete measures of equity incentive and the effect of the TongWang technology, and put forward the feasibility proposal to provide a useful reference for the improvement of equity incentive measures in private enterprises in China.

\section{Analysis on Incentive Mechanism of TongWang Technology Equity}

\subsection{Overall Situation of TongWang Technology}

TongWang Technology Co., Ltd. (hereinafter referred to as TongWang Technology, code: 430653). In 1997, it was registered in Zhuhai (state) high-tech industrial development zone in China, and officially listed in February, 2014 in the National Small and Medium Enterprise Share Transfer System (new three board).The company is specialized in the management research and information technology development of related business in the three major areas of project management, collaborative office and system integration, so as to meet the management requirements of customer 
growth, provide the solution of scientific system, and face the government administration organs and industry competent departments, project investment owners and construction enterprises. It is the key software enterprise of the Torch Plan Project of the Ministry of Science and Technology to provide services and technical-leading software products, management information integral solutions, and so on.

After more than a decade of rapid growth, TongWang Technology has become the preferred software product and service provider of three major areas, and its products and services are widely used in the fields of transportation, construction, petrochemical engineering, municipal utility and so on. At the same time, the core products and the whole solution of the continuous investment R \& D of Xinwang Technology have obtained the national key new product honor certificate, and popularized and applied in the whole country, and firmly established the high-quality brand image in the industry leading by TongWang Technology, and the "Quality Assurance of TongWang Technology" is well-known in the whole country.

TongWang Technology has more than 500 employees, has a R \& D team that is the mainstream of international information technology development, and a group of consulting experts with advanced international management theories and practical experience. By integrating the ISO9000 quality management system and the CMMI 3 software capability maturity model, the company establishes the united process management system, so as to form the core competitive advantage of the sustainable development of the software enterprise, and gradually transform into the differentiated customer value-"Leading business and technology, cost-effective products, duration and quality assurance projects".

By introducing the equity incentive program in 2015, the TongWang company realized the rapid growth. In 2016, the company realized the operating income 104 million yuan, which increased $29.37 \%$ compared with 2014 . The net profit is RMB $13,232,400$, increasing by $113.76 \%$, which realized the continuous three-year growth of net profit.

\subsection{Driving Force of the Equity Incentive}

TongWang Technology started to implement the equity incentive from Sep. 2015. For the needs of stimulating the company's business performance, it can be categorized into 3 reasons.

First, the company's operating state has declined, and it is necessary to encourage the management's working efficiency.

In 2013, the operating income of the Company is RMB 772.5 million. The operating income of the following year is only $3.843 \%$. The profit income of the half-year in 2015 is $6.0884 \%$. The profit-making situation of the Company is not optimistic, and management will need to be adjusted in time, so as to avoid the loss of future profits of the Company.In the resolution of the shareholders' meeting of the Company, the Company shall give the Company's senior management with stock option incentive, until the company's performance is improved.

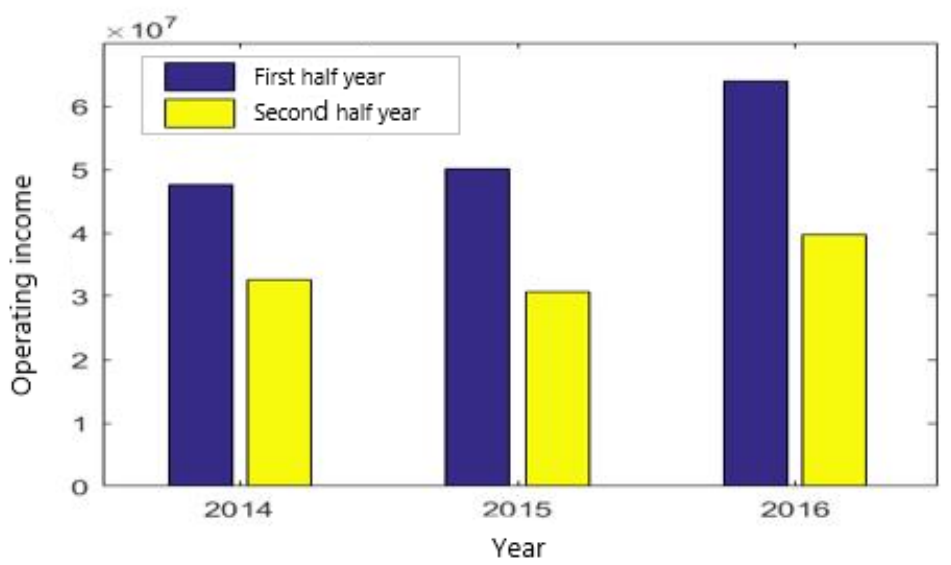

Figure 1. Half Annual Operating Income of TongWang Technology Company (2014 2016)

Second, the company encourages employees to hold shares and arouse the enthusiasm of production.

In July, 2015, the company published a notice to encourage employees to increase shares, compensate employees holding shares in the company, which indicates that the company's business foundation depends on the company's own talents, and encourages the technology employees to increase shares, thus contributing to strengthening the cohesion of the enterprise. According to the theory of human capital accumulation, the company not only needs to inspire and condense ordinary employees, but also should not neglect the importance of executive staff, especially the board of directors and manager, and their management decisions directly affect the future profits of the company. Therefore, adjusting the equity structure of the company, making equity incentive to the important senior management of the 
company is the need of the development of the company.

Thirdly, new subsidiary companies need talent investment.

In late 2015, the company proposed to set up an additional wholly-owned subsidiary, including Zhuhai Yinelastic Venture Capital Co., Ltd. (hereinafter referred to as Yinelastic Venture), as an example, with the registered capital of RMB 10 million in Hengqin New Area, Zhuhai City. The establishment of the new subsidiary will expand the industrial ecology of the parent company and affect the strategic layout of the company's long-term development. As a result of the need of construction of the Company, equity incentive to senior management personnel and technical personnel within the enterprise would contribute to the successful implementation of the new process of Yinelastic Venture.

The equity incentive scheme of TongWang Technology Co., Ltd., through the distribution of stock options, gives a total of 123 employees, including executives, supervisors, directors and managerial personnel of the Company and the business and technical backbone, accounting for $30 \%$ of the total number of employees. The program was adopted by the Third Plenary Session of the Third Meeting of Shareholders of TongWang Technology in 2015.Due to the fact that fewer incentive measures are used to reward the same-looking science and technology companies, the interference generated by multiple incentives can be reduced at the time of analysis, so as to meet the requirement of the incentive analysis. This text sets each window period for event as one year, and take the year 2015 as the time categorization point for the equity incentive event.

\subsection{Analysis of Key Points of Equity Incentive}

\subsubsection{Subject of Incentive}

The incentive target of the stock option program is the senior management personnel of the Company and the company supervisor, company level director, department manager, business and technical backbone, with a total of 123 people, accounting for 30\% of the total number of registered employees of the Company as at Jul 30, 2015.

The stock option scheme is used for granting the incentive target stock option in installments, wherein the total 5.13 million of the stock options of the incentive target is granted for the first time, and the remaining 470000 shares of the stock options are used for encouraging the newly-added talents with the incentive conditions during the performance evaluation period of the stock option scheme or the incentive personnel.

\subsubsection{Rights Exercise Time}

This stock option scheme is divided into three times, and shall be valid for up to 42 months from the date of award of the first-phase grant option to the date on which all stock options are issued or cancelled after the date of the performance of the stock option in the following three years, 2015, 2016 and 2017 respectively.

Table 1. Arrangement of equity incentive plan of TongWang Technology Co., Ltd.

\begin{tabular}{|c|c|c|}
\hline Vesting period & Vesting time & $\begin{array}{l}\text { The total number of vesting } \\
\text { rights as a percentage of the total } \\
\text { number of options granted }\end{array}$ \\
\hline $\begin{array}{l}\text { The first vesting period is } \\
\text { based on } 2014\end{array}$ & $\begin{array}{l}\text { From the first trading day of the completion of the } \\
\text { first vesting condition to the last trading day of the six } \\
\text { months following the completion of the first vesting } \\
\text { condition }\end{array}$ & $30 \%$ \\
\hline $\begin{array}{l}\text { The second vesting period } \\
\text { is based on } 2015\end{array}$ & $\begin{array}{l}\text { From the first trading day from the date of } \\
\text { achievement of the second exercise condition to the } \\
\text { last trading day within } 6 \text { months from the date of } \\
\text { achievement of the second exercise condition }\end{array}$ & $30 \%$ \\
\hline $\begin{array}{l}\text { The third vesting period is } \\
\text { based on } 2016\end{array}$ & $\begin{array}{l}\text { From the first trading day from the date of the third } \\
\text { exercise condition achievement to the last trading day } \\
\text { within } 6 \text { months from the date of the third exercise } \\
\text { condition achievement }\end{array}$ & $40 \%$ \\
\hline
\end{tabular}

\subsubsection{Exercise Conditions}

The equity incentive scheme of TongWang Technology Co., Ltd., according to the overall performance of the company, combines the performance appraisal grade of the incentive object, and determines the proportion of the incentive target to which the option has been awarded. 
Table 2. Proportion of equity incentive schemes of TongWang Technology Co., Ltd. (as a percentage of the number of shares granted)

\begin{tabular}{|c|c|c|c|}
\hline $\begin{array}{l}\text { Overall performance of the } \\
\text { company }\end{array}$ & A Staff & B+ Staff & B Staff \\
\hline $\begin{array}{l}\text { The company's operating income } \\
\text { and net profit increased by more } \\
\text { than } 30 \% \text { from the previous year }\end{array}$ & $100 \%$ & $80 \%$ & $70 \%$ \\
\hline $\begin{array}{l}\text { The company's operating income or } \\
\text { net profit increased by more than } \\
30 \% \text { from the previous year }\end{array}$ & $80 \%$ & $60 \%$ & $50 \%$ \\
\hline $\begin{array}{l}\text { The company's operating income } \\
\text { and net profit increased by less than } \\
30 \% \text { from the previous year }\end{array}$ & $50 \%$ & $40 \%$ & -- \\
\hline
\end{tabular}

On September 15, 2015, TongWang Technology adopted the "Proposal on the consideration of the incentive scheme for the equity of TongWang Technology" and "Proposal on the Issuance of Employee Stock Options to 119 Employees as LI Chunhua", "A Proposal on the Grant of Stock Option to Pan Pu and Xu Yue" and "Proposal on Granting Stock Options to the President of Board of Supervisors LI Qiuyue and He Chun the supervisor" of the third meeting of the General Assembly of the Third Meeting of the Interim Shareholders of TongWang Technology Company by 2015, and determined that the number of incentive targets for equity is 123 , and the total number of incentive schemes stock options is 5.6 million.

By December 31, 2016, the average price in the first 60 trading days of the company is 4.47 yuan. The price of the option is higher than the market price, so the company option belongs to the outer-price option.

\subsection{Effectiveness Analysis of Equity Incentive of TongWang Technology Co., Ltd.}

\subsubsection{Financial Performance Evaluation}

This paper chooses the financial statement data in the second half of 2015 and first half of 2017 after TongWang Technology Company implemented the equity incentive scheme. Considering the size of each subsidiary of the company is not large, the report type used for analysis selects the form of consolidated report. According to the data of the financial statements, the main financial indicators of the same company are calculated as follows, as shown in Table 3.

Table 3. Financial Indicators of TongWang Technology Co., Ltd. (2013-2016)

\begin{tabular}{lllll}
\hline Financial index & 2013 & 2014 & 2015 & 2016 \\
\hline Operating income & 7725.11 & 8022.01 & 8085.18 & 10378.01 \\
Cash received from sales & 8039.19 & 8319.34 & 7999.56 & 11128.85 \\
Net profit & 257.39 & 619.04 & 786.47 & 1323.24 \\
Net cash flow from operating activities & -753.14 & 1549.09 & 1732.22 & 2940.79 \\
Net profit growth rate (\%) & NA & 140.51 & 27.05 & 68.25 \\
Net Profit Margin on Sales (\%) & 3.33 & 7.72 & 9.73 & 12.75 \\
ROE (\%) & 2.39 & 5.44 & 6.28 & 9.74 \\
ROA (\%) & 1.78 & 4.17 & 4.69 & 8.13 \\
Current ratio & 1.93 & 2 & 1.98 & 2.7 \\
Quick ratio & 1.89 & 1.97 & 1.94 & 2.5 \\
Time interest earned ratio & 3.57 & 5.38 & 5.85 & 16.86 \\
Equity multiplier & 1.34 & 1.31 & 1.34 & 1.2 \\
Current asset turnover & 1.1 & 1.16 & 0.98 & 1.48 \\
Total asset turnover & 0.53 & 0.54 & 0.48 & 0.64 \\
Ratio of cash received from goods and services to & 1.04 & 1.04 & 0.99 & 1.07 \\
sales revenue & & & 2.93 & 2.22 \\
Ratio of net operating cash flow to net profit & -2.93 & 2.5 & 2.2 \\
\hline
\end{tabular}

Note: For the calculation formula, see the appendix section. All data comes from the CSMAR.

(1) Analysis of income and profit quality

The quality of revenue and profits can be measured from two aspects of growth and cash content. The absolute analysis can select operating income, sales cash income, net profits and net cash flow of operating activities as an analysis index. It reflects the growth of revenue and profits between 2013 and 2016 of TongWang Technology Company. As can be 
seen from the figure, corporate income and net profit growth was slow before the implementation of the equity plan in 2015, and the earnings and profits of the company were increasing following the implementation of the plan.

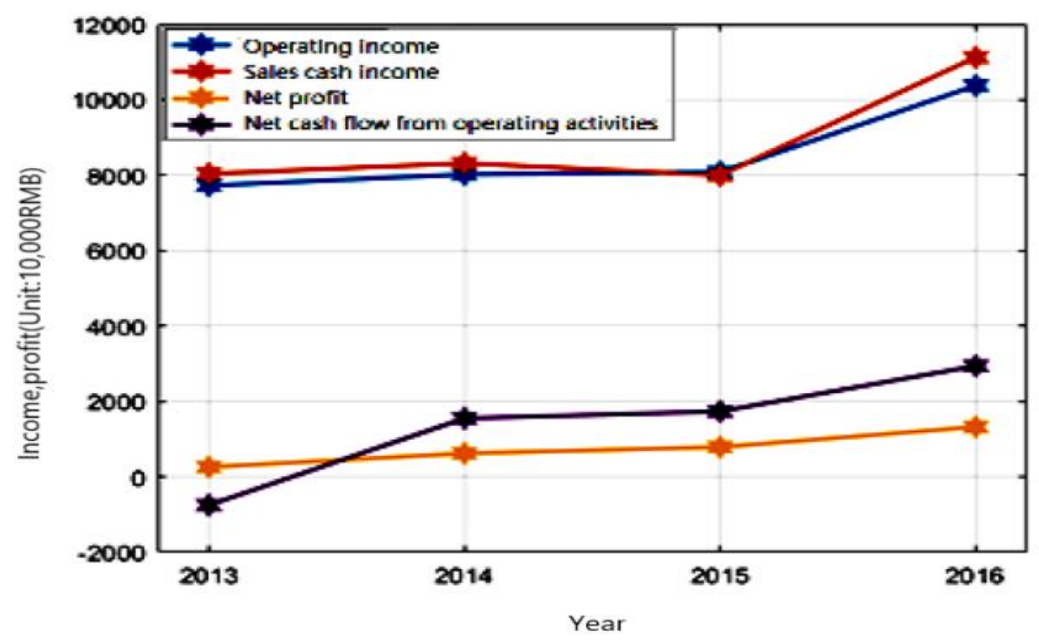

Figure 2. Variation trend chart of income and profit index of TongWang Technology Co., Ltd.

In addition to the absolute indicator analysis, the improvement effect of the equity incentive scheme to the enterprise management can also be reflected by the relative indexes. In 2015, the company's profitability declined, the company's net profit growth decreased from $140.51 \%$ to $27.05 \%$. The company's net profit growth slowed sharply. After the equity incentive scheme was implemented, the net profit of the company reached 13.2324 million yuan in 2016, and the growth rate reached $68.25 \%$. The equity incentive scheme achieves the goal effect of enhancing the profitability of the enterprise.

The cash ability of the technology company also reflects the company's ability to operate continuously. The more cash held, the stronger the ability to maintain high technicians and to maintain the day-to-day maintenance of equipment and the higher the degree of security of the enterprise. The cash ability of enterprises can be identified through the cash content of income and profits. Generally speaking, the sales closing rate and net profit collecting rate are selected as the reaction indexes of enterprise income and profit quality.

The sales collection rate of TongWang Technology Co., Ltd. was maintained at 107\% in 2016, which shows that the normal operation of the enterprise is guaranteed, and the quality of revenue is high. In general, the cash net flow of operating activities continues to be positive and consistent with changes in net profit indicators, reflecting the higher cash content of profits of the company. In addition to the apparent loss of the enterprises in 2013, the cash net flow rate of the operation activities of the same company from 2014 to 2016 continued to be positive, and the growth rate rose sharply after the implementation of the equity incentive scheme, with a growth rate of $69.77 \%$, which reflected high profit quality.

(2) Analysis of profitability

The return index of net assets can reflect the core profitability of the company. From the point of view, before the equity incentive scheme is implemented, the return rate of the net assets of the company is only 5.44\%. Although it exceeds the average level of the industry, it is unfavorable to the development of the enterprise, and shareholders always require higher remuneration for their assets, as shown in Table 4. In contrast, the net assets return rate of TongWang Technology Co., Ltd. reached $9.74 \%$ in 2016, which went well beyond the industry level in the same period and increased substantially on a year-on-year basis. The company's profitability is further strengthened under the incentive of equity, which fully explains the work and effectiveness of the company's executives.

Table 4. Comparison of net assets return rate and industry in TongWang Technology Co., Ltd.

\begin{tabular}{lcc}
\hline Year & Industry & TongWang Technology \\
\hline 2013 & 0.12 & 2.39 \\
2014 & 0.12 & 5.44 \\
2015 & 0.08 & 6.28 \\
2016 & 0.06 & 9.74 \\
\hline
\end{tabular}


Figure 3 is the asset return situation of listed companies in the information science and technology industry of the new third board market in China in 2016, and it can be seen that the profitability of the new three-board market information technology enterprises is generally low, and only less enterprises can realize the excess yield.

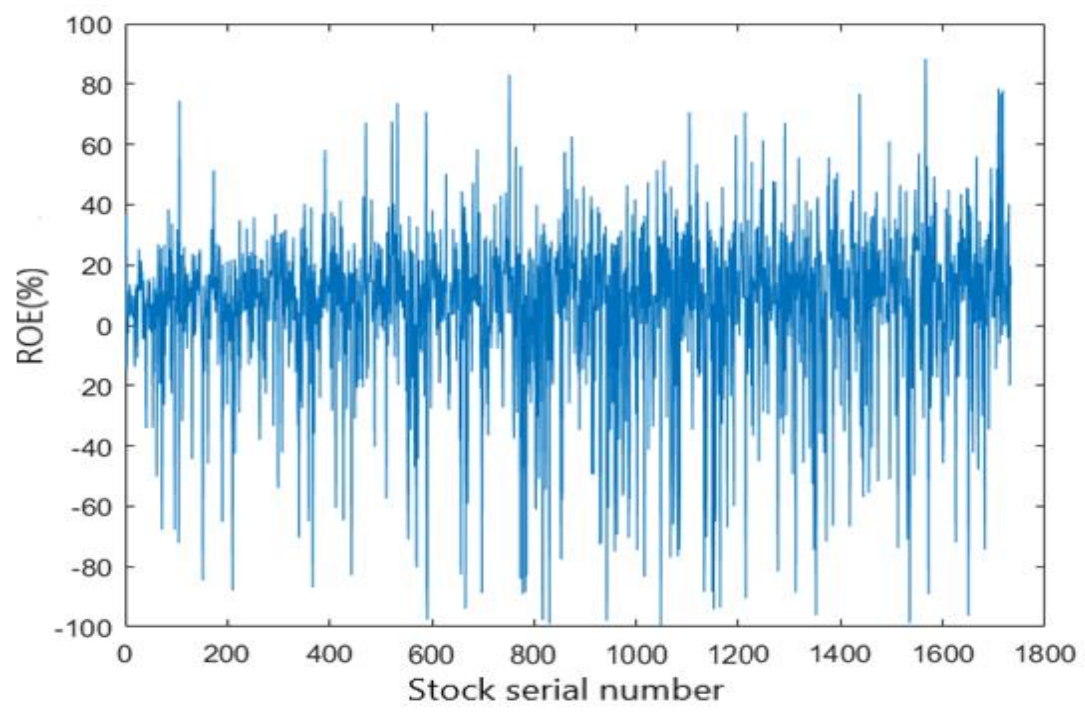

Figure 3. Information Technology Industry Company Net Assets Return Sequence

In order to further analyze the change of net assets return rate of TongWang Technology Co., Ltd., this paper adopts the DuPont analysis system to decompose the return rate of net assets into the product of net interest rate, total asset turnover and equity multiplier. From the point of view, we can see that the net interest rate of the TongWang Technology company has steady growth, which shows that the company's product itself has a considerable profit, and the value-added capability is strong. From the total asset turnover rate, the ability of the company to change the assets before the equity incentive scheme is implemented is poor, the annual sales income can only replace the half of the assets, the total asset turnover of the company even declines in 2015, and the overall operation situation of the company is not optimistic. After equity incentives, the situation has improved and the pace of asset turnover has accelerated.

Table 5. DuPont analysis index decomposition of net assets return rate of TongWang Technology Co., Ltd.

\begin{tabular}{cccll}
\hline Year & ROE $(\%)$ & Net Profit Margin on Sales $(\%)$ & Total asset turnover & Equity multiplier \\
\hline 2013 & 2.39 & 3.33 & 0.53 & 1.34 \\
2014 & 5.44 & 7.72 & 0.54 & 1.31 \\
2015 & 6.28 & 9.73 & 0.48 & 1.34 \\
2016 & 9.74 & 12.75 & 0.64 & 1.2 \\
\hline
\end{tabular}

The company's financial position can be reflected in the balance sheet. From the structure of the balance sheet, the debt level of the same technology company decreased by $36.92 \%$ in 2016 , the shareholder's equity increased by $8.24 \%$ in the same period, the overall financial leverage was reduced, and the overall debt ratio of the company decreased from $25.39 \%$ in 2015 to $16.52 \%$, at a relatively good level. Seen from above, the company maintains a strong debt-paying ability, the current ratio is 2.7, can meet the repayment of short-term liabilities, and also has a very high interest guarantee multiple at the same time, and has a high degree of guarantee for debt repayment.

\subsubsection{Analysis of Management Behavior}

According to the incentive theory, the effective equity incentive scheme can influence the psychology of the executive staff and influence the daily behavior. Because the incentive amount of the equity is large, and the interest is linked with the performance of the company, the executives will try to reduce the day-to-day expenses of the company in order to achieve the achievement goal specified by the equity incentive scheme, and reflect the decrease of the sales expense and the management cost on the profit statement. The loan interest is mainly used to pay the loan interest, which has little influence on the behavior factor of the manager, so it is not taken as an analysis index. This paper analyzes whether the management of the TongWang technology company has received the influence of equity incentive, which leads to the change of business behavior by comparing the management cost and the sales cost to its operating income as an index to study whether the financial effect of equity incentive is effective. 


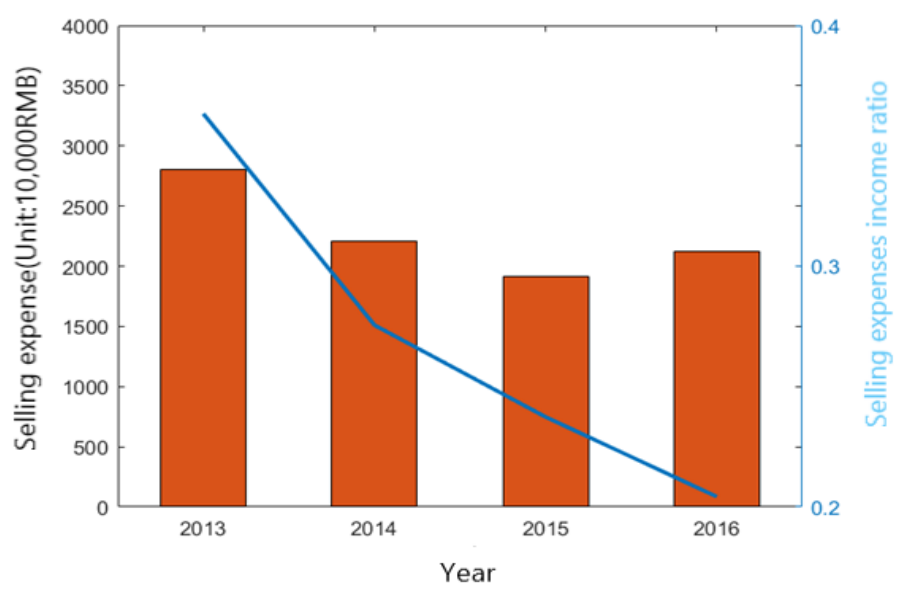

Figure 4. Variation trend of sales expense and sales expense income ratio of TongWang Technology Co., Ltd.

It can be seen that during the period from 2013 to 2016, the company reported a downward trend in the overall sales expenses during the operation of the company. At its lowest level in 2015, there are indications of a slight rise in sales expenses in 2016, but it can be seen that the sales expense income is lower than this index. The sales revenue growth of the company is the main reason to increase the sales expense, and the overall downward trend of the sales expense income ratio shows that the company manager has better control over the sales expense, and the equity incentive scheme stimulates the company manager so that it has to strictly control the sales expense.

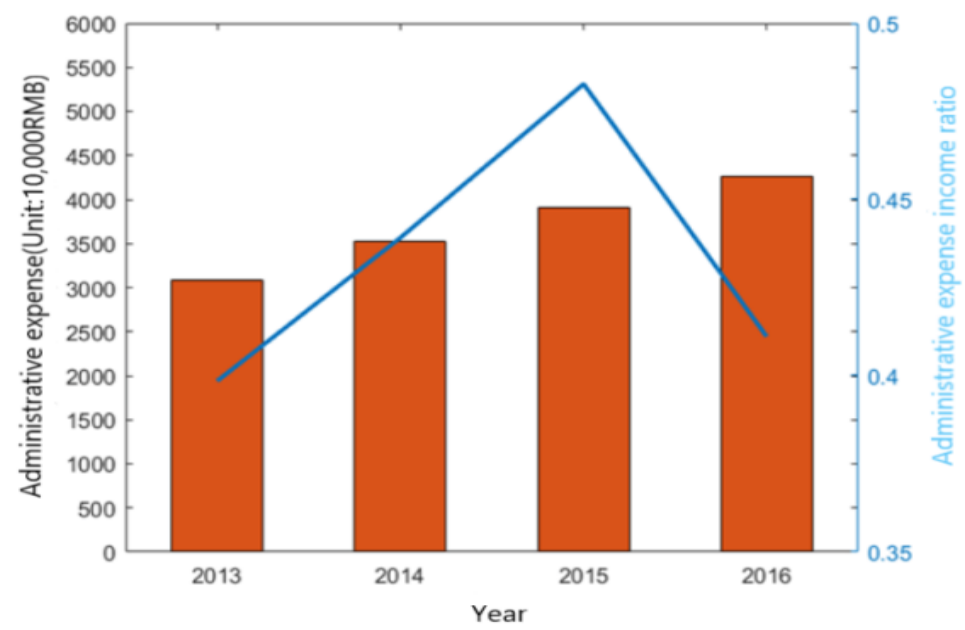

Figure 5. Variation trend of the ratio of administrative expenses and management expenses in TongWang Technology Co., Ltd.

On the other hand, from the perspective of the management of the company, the company manager has the will to control the operation cost of the enterprise, including various kinds of unnecessary business operation expenses, which shows the decrease of the management cost of the company. As a result, the management cost of the company is not a downward trend, and the ratio of management expense and sales revenue is greatly reduced after the implementation of the equity incentive scheme. According to the above analysis, it is not difficult to conclude that the company's management costs are difficult to absolute decline because of the growth in the company's sales, while the company's management costs fall significantly relative to the company's sales revenue.

In 2016, TongWang Technology Co., Ltd. set up a number of network science and technology subsidiary companies. Business expansion brings business income growth and sales expense and management expense rise. Compared with the comparative analysis, it is concluded that the company manager is affected by the equity incentive scheme. Actively adjust the operation condition of the company, reduce the expense expenditure, and bring substantial revenue effect to the enterprise. 


\subsubsection{Market Performance Evaluation}

After the transaction of TongWang technology on the new three board is concluded after the bull market at the end of 2014, most of the transactions are in private agreement. The market is cold, and the information reflection degree of the equity incentive scheme is not high. Therefore, it is not suitable to study the influence of the equity incentive scheme from the stock market to the stock price. And the stock market's response to the equity incentive scheme can be reflected by the change of the trading volume of the stock.

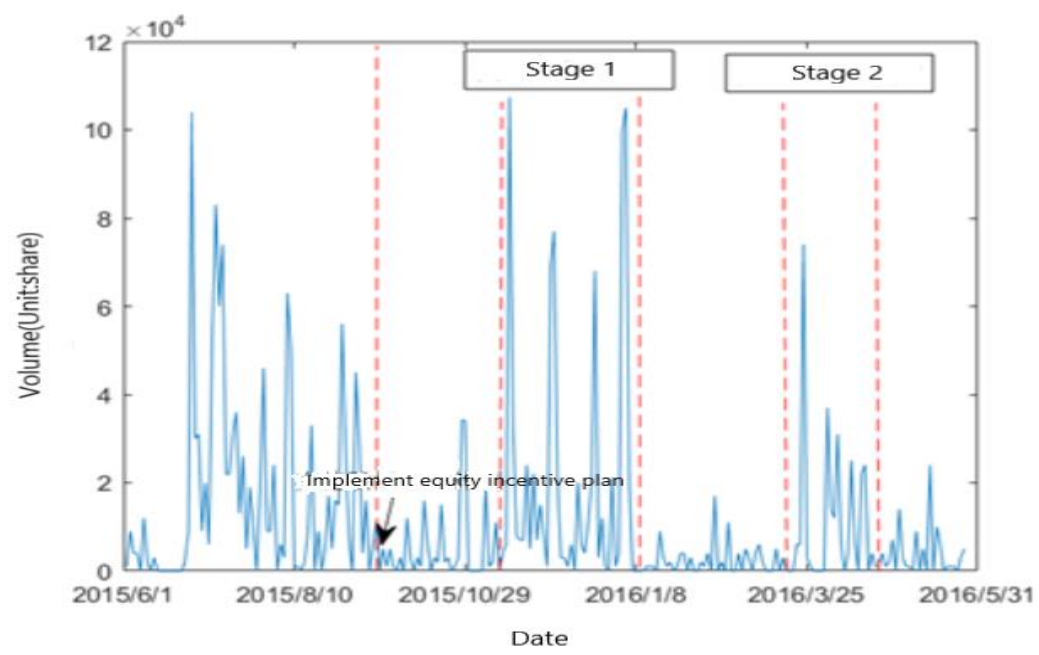

Figure 6. Tendency Chart of Shares Trading Volume of TongWang Technology Co., Ltd.

Shares trading volume of TongWang Technology Co., Ltd. has been reduced after the stock market suffers from coldness. Most of the subsequent shares deal with the adjustment of the internal structure, few enterprises outside the enterprise enter the stock exchange market of the same looking technology. And by analyzing the change of the trading volume of the stock, it is found that the trading volume of TongWang Technology Company is subject to greater vibration after the equity incentive plan is implemented. It is assumed that the employees who obtain the shares option trading rewards will exercise their rights in a centralized manner after meeting the market conditions, so that the trading volume of the stock rises rapidly.

\section{Case Revelation}

The reason why stock ownership incentive is effective mainly comes down to the following four points:

\section{(1) Set a reasonable range of incentives}

One of the biggest characteristics of its equity incentives is the wide range of incentives. The number of employees giving stock option awards is 123 , covering $30 \%$ of employees. Greater coverage of employees can result in a wide range of incentives. If only certain executives are rewarded to cause dissatisfaction with other employees, it is possible to create a result that the incentive effect is not ideal or even negative.

(2) Rational setting of validity period

One year interval between the unlocking periods set by the equity incentive scheme of TongWang Technology. Multiple unlocking can generate long-term incentive for the enthusiasm of the employees. And the validity period of a long time can better measure the performance of the employees. The speculators should prevent the speculators from cheating on the performance of the performance appraisal for short-term performance appraisal.

(3) Appropriate Time of Stock Option

In the first time, 5.13 million shares the total options of the incentive target stock option, and the remaining 470000 share options are used to encourage the stock option scheme to meet the incentive conditions in the performance appraisal period. The grant of stock option can only show the employee's enthusiasm and the effect of equity incentive.

(4) Harsh rights exercise conditions

The rights exercise conditions of TongWang Technology in previous two years are 30\% higher than the operation revenue and net profits. In order to meet this condition, the company's staff have to compete with each other for their performance, and at the same time, they will not be able to achieve the same conditions. To a certain extent, the incentive scheme of the TongWang Technology is promoted effectively. 


\section{References}

Brickley, J. A., Bhagat, S., \& Lease, R. C. (1985). The impact of long-range managerial compensation plans on shareholder wealth. Journal of Accounting \& Economics, 7(1), 115-129. https://doi.org/10.1016/0165-4101(85)90031-X

Demsetz, H., \& Lehn, K. (1985). The structure of corporate ownership: causes and consequences. Journal of Political Economy, 93(6), 1155-1177. https://doi.org/10.1086/261354

Himmelberg, C. P., Hubbard, R. G., \& Palia, D. (2000). Understanding the determinants of managerial ownership and the link between ownership and performance. Journal of Financial Economics, 53(3), 353-384. https://doi.org/10.1016/S0304-405X(99)00025-2

Huang, G. T., \& Zhang, Y. (2008). 30-year Enterprise Reform: Management Incentive Effect—Sample Analysis Based on Listed Companies. Financial Studies, (12), 101-112.

Jensen, M. C., \& Meckling, W. H. (1976). Theory of the firm: management behavior, agency cost and ownership structure. Journal of financial economics, 3(4), 305-360. https://doi.org/10.1016/0304-405X(76)90026-X

Liu, G. L., \& Wang, J. S. (2000). Empirical Study on Ownership Structure, Incentive System and Performance of Listed Companies. Economic Theory and Economic Management, (05), 40-45.

Mehran, H. (1995). Executive compensation structure, ownership, and firm performance. Journal of Financial Economics, 38(2), 163-184. https://doi.org/10.1016/0304-405X(94)00809-F

Morck, R., Shleifer, A., \& Vishny, R. W. (1988). Management ownership and market valuation: An empirical analysis. Journal of Financial Economies, 20(1-2), 293-315. https://doi.org/10.1016/0304-405X(88)90048-7

Tian, X., \& Meng, Q. Y. (2018). Can equity incentive programs promote enterprise innovation..Nankai Management Review, 21(03), 176-190.

Wang, Q. X., \& Chen, X. Y. (2009). Empirical Study on Economic Performance of Equity Incentive in Listed Companies. Friends of Accounting (Mid-Year), (11), 79-82.

Xia, Y. (2014). Managers' Power, Equity Incentive and R \& D Investment - Empirical Analysis Based on China's Listed Companies. Research and Development Management, 26(04), 12-22.

Xiao, S. G., \& Yang, J. (2018). Is Executive Equity Incentive Promoting Enterprise Upgrades? Empirical Evidence from China's Listed Companies. Nankai Management Review, 21(03), 66-75.

Yu, H. L. (2006). Empirical Test on the Incentive Effect of Managers' Equity in State-owned Listed Companies. Economic Sciences, (01), 108-116.

Zhou, J. B., \& Sun, J. S. (2003). Research on Governance Effect of Operator Equity Incentive- empirical evidence from Chinese listed companies. Economic Research, (05), 74-82 + 93.

\section{Copyrights}

Copyright for this article is retained by the author(s), with first publication rights granted to the journal.

This is an open-access article distributed under the terms and conditions of the Creative Commons Attribution license which permits unrestricted use, distribution, and reproduction in any medium, provided the original work is properly cited. 